ZOOLOGIA 30 (3): 249-254, June, 2013

http://dx.doi.org/10.1590/S1984-46702013000300001

\title{
Diet of Monodelphis glirina (Mammalia: Didelphidae) in forest fragments in southern Amazon
}

\author{
Welvis Felipe Fernandes Castilheiro', \& Manoel dos Santos Filho ${ }^{1}$
}

\author{
${ }^{1}$ Centro de Pesquisa de Limnologia, Biodiversidade e Etnobiologia do Pantanal. Avenida Santos Dumont, Cidade Universitária, \\ 78200-000 Cáceres, MT, Brazil. \\ 2 Corresponding author. E-mail: welvisfelipe@gmail.com
}

\begin{abstract}
The current study aimed to evaluate the diet of Monodelphis glirina (Wagner, 1842) in forest fragments of Alta Floresta, located in the south of the Amazon, state of Mato Grosso. The diet was determined by the analysis of the stomach contents from 57 subjects sampled between May and September 2009. Nine food categories were present: Coleoptera, Orthoptera, Hymenoptera, Diplopoda, Nematoda, seeds, miscellaneous, hair and bait leftovers (banana and peanut butter). Coleoptera was the category eaten most frequently, rating $50 \%$ of abundance and $91.22 \%$ of occurrence. "Seeds" were the least abundant $(0.11 \%)$ and rated $1.75 \%$ in occurrence, probably because seeds are easy to digest. The size of the fragments negatively and significantly influenced the amount of Coleoptera in the diet. The rainy season seemed to have significant influence over the abundance of arthropods in the diet. The items in the diet suggest that M. glirina is opportunistic and has a generalist diet, tending to be insectivore when living in the forest and exploring the food resources according to their availability.
\end{abstract}

KEY WORDS. Coleoptera; food items; fragmentation; insectivore.

In Brazil, Didelphidae consists of 16 genera and 55 species. These small mammals play an important role in ecosystems due to their broad distribution, and the fact that they occupy diverse niches (Reis et al. 2006). Most representatives of this family live in forests, and for that reason they are threatened by the fragmentation process (NowaK 1991, Emmons \& FeER 1997, Laurance \& BierregaArd 1997). In the southern Amazon, mainly in Alta Floresta, some areas are highly fragmented (Fernandez \& Pires 2006). Fragmentation has been caused by wild fires and human occupation that includes illegal settlements, deforestation, agriculture, cattle ranching and timber extraction. All these have caused changes in the ecosystem, including, but not limited to, food availability (MurCia 1995, Michalski \& Peres 2005).

Furthermore, fragmentation intensifies edge effects (Lovejoy et al. 1986, Murcia 1995). The resulting pressure and oscillation can change the diet of didelphids.

One way to understand how these little mammals behave and survive these disturbances is through the study of their diets (Lovejoy et al. 1986, Murcia 1995).

"Diet" is one of the interesting features in the autecology and organization of dildelphids. Marsupials are generalists and can also be insectivores, frugivores and, in general terms, omnivores. What they eat may vary according to age, reproduction and time of the year (CASELla \& CÁCERES 2006).

The significance of studying the diet of didelphids becomes clear in the context of understanding the structure and the rela- tionship among communities in fragmented areas, besides the analysis of the energy rates and demographic aspects that can work as references in the management of these impacted areas. The species studied herein, Monodelphis glirina (Wagner, 1842 ) is basically terrestrial (NowaK 1991, EMmons \& FeER 1997). However, there is no information about its feeding habits, reproduction and conservation status (Reis et al. 2006). In Brazil, the species is found in the southern part of the Amazon River and west of the Xingu River, as well as to the north of Bolivia (GARDNER 2005).

In this contribution, we provide data on the feeding habits of M. glirina. Studies of this nature, for this species, had not been carried out before. Specifically, we aimed to evaluate whether there are differences in the diet of this species according to: classes of development, months of sampling, sex and size fragment.

\section{MATERIAL AND METHODS}

The study was performed in forest fragments of the Southern Amazon, located in Alta Floresta, in the northern part of the state of Mato Grosso. Fourteen (14) fragments, of different sizes and located in pasture matrixes were sampled (Fig. 1).

The Alta Floresta is highly fragmented, with medium and large sized trees. Landscape fragmentation has been caused by cattle ranching, extensive road paving and many large rural settlement programs which started in 1975 . Timber extraction, 


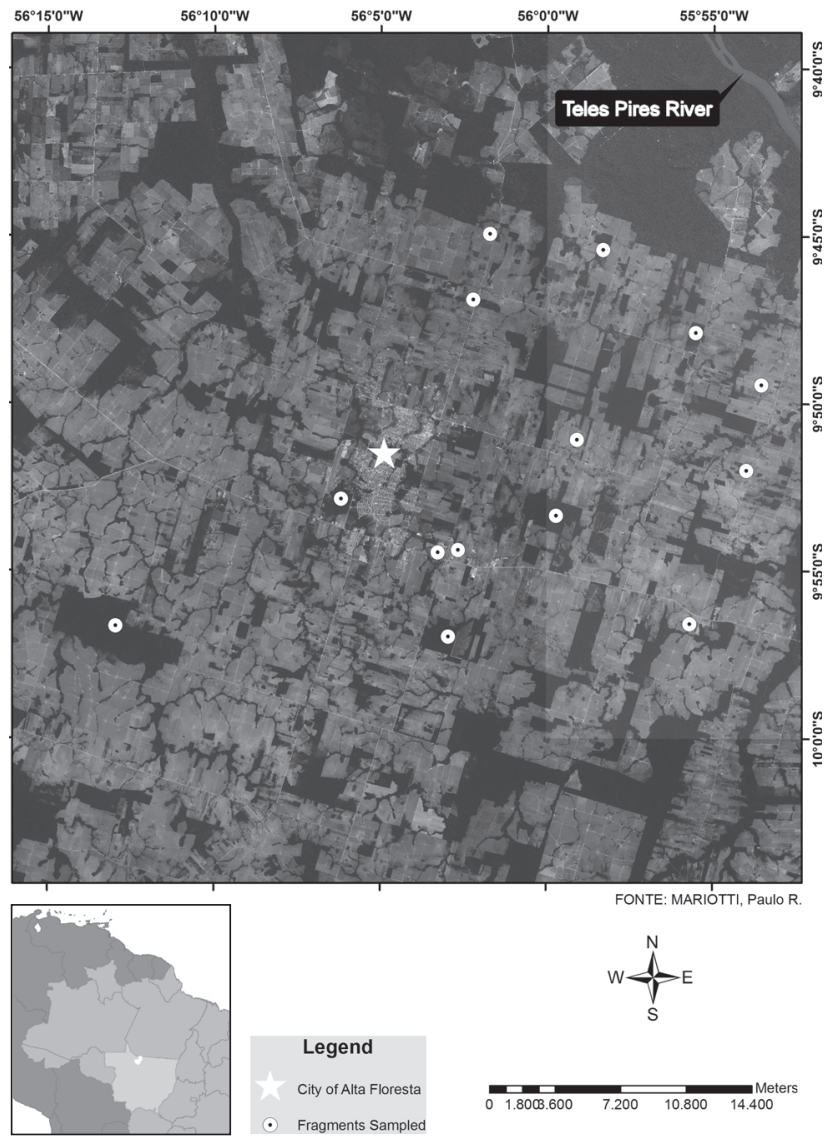

Figure 1. Forest fragments in Alta Floresta, Mato Grosso, Brazil.

wildfires and illegal hunting still affect the region. Before 1976, the region was entirely covered with intact Amazonian land. Subsequently, deforestation of the area increased exponentially. In 2003, 37\% of the forest coverage remained in Alta Floresta, which is an ideal landscape model for studying fragmentation effects in the habitat (Michalski \& Peres 2005).

We spent ten consecutive nights in each fragment, in order to conduct the sampling, which happened between May and September 2009. There were 14 forest fragments: four small ones ( 2 to $7 \mathrm{ha}$ ), six mid sized (15 to $141 \mathrm{ha}$ ), and four large fragments (787 to $1763 \mathrm{ha}$ ). Conventional traps such as: Tomahawk (145 x $145 \times 410 \mathrm{~mm})$, Sherman ( $80 \times 90 \times 230 \mathrm{~mm})$, as well as intercepting pitfall traps (60-litre bucket), were used for sampling the subjects.

The sampling module, with conventional traps, was set with three main parallel tracks, each $80 \mathrm{~m}$ long and placed $50 \mathrm{~m}$ away from each other, inside the fragments. Five sampling points were set in each transect, placed $20 \mathrm{~m}$ away from each other. Two traps were set in these points, one using the Sherman type and another using the Tomahawk type on the ground, and placed $3 \mathrm{~m}$ away from each other, grouping a total of 10 traps in each track and 30 by sampling module. Only one sampling module was installed in the small fragments and three in the mid and large ones, all of them placed $500 \mathrm{~m}$ away from each other.

In addition, in the intervals among tracks, intercepting and fall trap sampling modules were installed, using the " $\mathrm{Y}$ " shape in each sampled area. Each pitfall trap module was $30 \mathrm{~m}$ long. The $60 \mathrm{~L}$ buckets were bared all the way up to the edge, in holes on the ground and linked to the surface by a $70 \mathrm{~cm}$ high black plastic tarpaulin guide fence, supported by wooden stakes held by clamps. The tarpaulin was kept stretched and its underside was buried $5 \mathrm{~cm}$ down into the ground. Only one module was installed in the mid and large ones, four buckets were placed in the centre of each area, among the tracks of the conventional traps. Four modules were installed in the mid and large fragments and placed $500 \mathrm{~m}$ away from each other.

The conventional traps were baited with banana and peanut butter. After the capture, skulls, post-skulls and tissue were sampled. The animals went through a taxidermy process and are stored at the Mammalogy Lab of the Universidade do Estado de Mato Grosso (UNEMAT), Cáceres, Mato Grosso, Brazil.

The dietary composition was determined by the analysis of stomach contents (UIEDA 1994). The stomach of each specimen was pulled out and stored in formaldehyde (10\%) for one day. After that, the stomachs were washed in freshwater and transferred to alcohol 70\%. Subsequently, the stomach content was removed and dissolved in $20 \mathrm{ml}$ of distilled water in millimetre-scaled Petri dish (Fernandes et al. 2006). The material from the stomach was analyzed using a stereoscopic microscope and Pipette tips (Fernandes et al. 2006). The items found in the contents were divided into categories.

The determination of age classes was based on the eruption of molars and pre-molars, in regards to three classes of development: juvenile - subjects presenting the last superior molar as the first $\left(\mathrm{M}^{1}\right)$ or the second $\left(\mathrm{M}^{2}\right)$ (animals independent from their mothers but yet sexually immature); sub-adults - subjects presenting the third superior molar functional $\left(\mathrm{M}^{3}\right)$ (sexually active); and adults - subjects presenting complete dentition $\left(\mathrm{M}^{4}\right)$ (sexually active) (Cordeiro \& Nicolas 1987, Tribe 1990, MACEDo et al. 2006).

The stomach repletion degree was estimated and determined according to the amount of food found in it. It was possible to visually verify whether the stomach was partially or totally empty (0-25\%), whether it presented intermediate or low amounts (25-50\%), or high amounts (50-75\%) of food, and whether it was full of food (75 to 100\%) or not - (UIEDA 1994). The frequency of occurrence and the specific prey abundance (numeric frequency) (Hynes 1950, Hyslop 1980, Uieda 1994) were combined and calculated in order to be analyzed by means of the Costello's diagram method (Costello 1990). This graphic method can demonstrate the availability of food resources in the region, allowing estimations regarding the selectivity of the predator and the availability of the species used as prey. We also combined data of specific prey abundance and vol- 
ume, aiming to determine the Importance Food Index (IFI) (variable from 0 to 1 ), which allowed an evaluation on the food regimen and the most important aspects of it (KAWAKAMI \& VAZZOLER 1980).

The Lilliefors test was used to check the normality of the raw data set for regression analysis. The linear regression analysis was used to evaluate the influence of the independent variable (size of the fragment) and the dependent variable (Coleoptera, Orthoptera, Hymenoptera and Diplopoda) present in the diet and the number of captured subjects. All the analyses were performed using the program $\mathrm{R}$ version 2.14.0.2011 (R Development Core Team 2011).

\section{RESULTS}

Fifthy seven (57) subjects were analyzed ( 28 females and 29 males). Their mean body length was $182.4 \pm 30.9 \mathrm{~mm}$; tail length $64.1 \pm 9.4 \mathrm{~mm}$; ear length $15.9 \pm 2.0 \mathrm{~mm}$; paw lenght $18.6 \pm 2.2 \mathrm{~mm}$ and mean total weight $52.0 \pm 26.7 \mathrm{~g}$. According to the degree of stomach repletion, 15 subjects had totally or partially empty stomachs, 14 showed low-intermediate repletion, 23 presented high-intermediate repletion and only five subjects had a full stomach (Fig. 2).

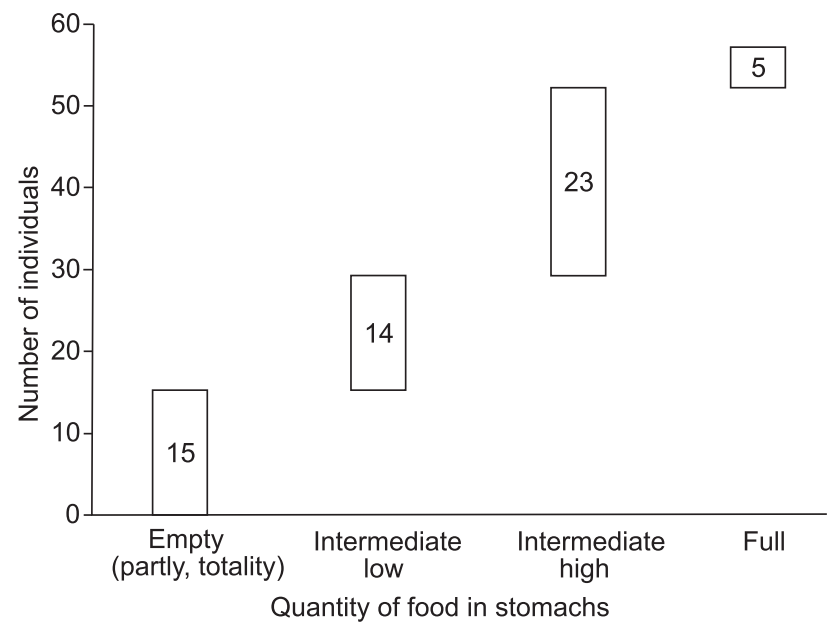

Figure 2. Waterfall chart showing the degree of repletion of the stomachs of Monodelphis glirina individuals.

In total, nine categories were observed: Coleoptera, Orthoptera, Hymenoptera, miscellaneous, seeds, Diplopoda, Nematoda, hair and bait leftovers. The category miscellaneous refers to all vegetable material which was not identified at any taxonomic level. The calculation of abundance, frequency of occurrence and IFI, for the categories Nematoda and bait leftovers were estimated. However, Nematoda is not a food category and baits do not take part in the natural diet of the species.
The category Coleoptera showed the highest abundance (50\%) with a frequency of occurrence of $91.22 \%$ and IFI of 0.2472 in the diet of M. Glirina. The category "seeds" presented the lowest abundance $(0.11 \%)$, with frequency of occurrence of $1.75 \%$ and IFI of 0\% (Table I). In general, according to CostelLo's (1990) diagram, the category Coleoptera was prominent and the other categories were considered rare in the diet (Fig. 3).

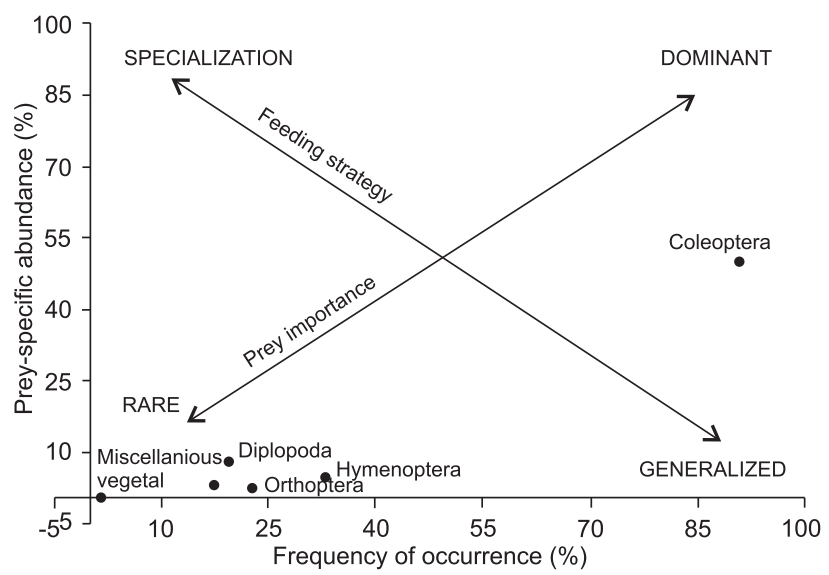

Figure 3. Costello's diagram showing the relationship between frequency of occurrence and prey abundance in the diet of Monodelphis glirina.

Among male and female subjects, the category Coleoptera was prominent and the other categories were rare. The category "seeds" was recorded only in the diet of female subjects (Table I).

In all classes of development, the category Coleoptera was preponderant, and the other categories were considered rare in the diet. Among juvenile subjects, the diet was less diverse, the categories Diplopoda, Orthoptera and seeds did not appear. In the sub-adult class, only Diplodopa was not recorded and in the adult class, and the category "seeds" did not appear in the diet (Table I).

The size of the fragments had a significantly negative influence $\left(\mathrm{R}^{2}=27.59 \%, \mathrm{p}=0.0297\right)$ in the frequency of occurrence of Coleoptera in the diet of M. Glirina. In the small fragment ( $2 \mathrm{ha}$ ), the frequency of this prey corresponded to $100 \%$; in the mid fragment (141ha), it came down to $80 \%$, and in the largest fragment (1763 ha), the frequency decreased to 50\% (Fig. 4).

The correlation was significant $(p=0.0225)$ among the abundance of arthropods (Coleoptera, Orthoptera, Hymenoptera, Diplopoda) present in the diet and the number of subjects captured each month. Those food items were more abundant in May and September, matching the greater number of captured subjects. The months of June, July and August were those with less arthropods, matching the fewer numbers of captured subjects (Fig. 5). 


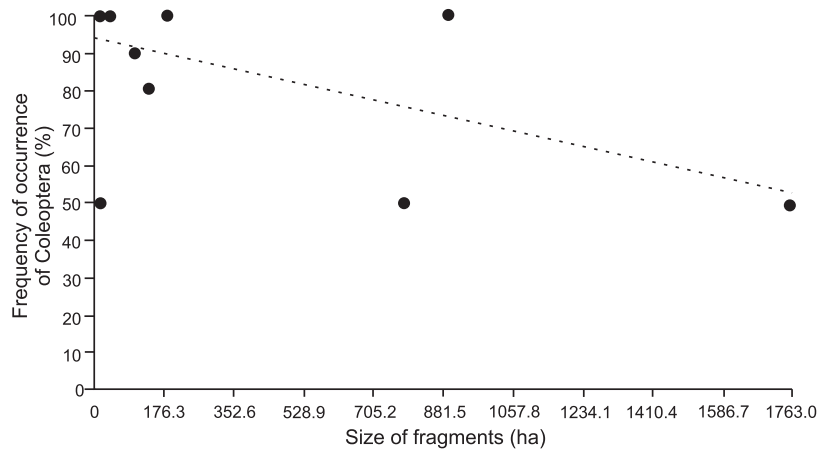

Figure 4. Linear regression showing the influence of forest fragment size on the frequency of occurrence of Coleoptera.

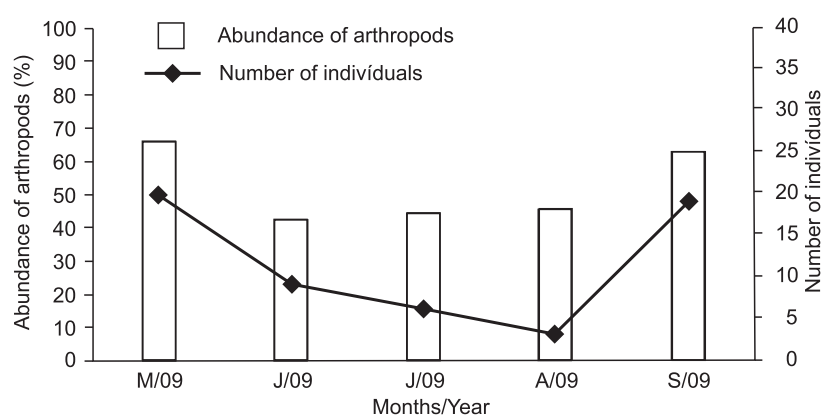

Figure 5. Arthropod abundance (Coleoptera, Orthoptera, Hymenoptera, Diplopoda) in the diet and the relationship of it with the amount Monodelphis glirina subjects.

Cylindrical endoparasite worms from the phylum Nematoda were found in the stomach of 19 subjects, all adults, showing abundance of $1.47 \%$ and frequency of occurrence of $33.33 \%$ (a total of 57 subjects were analyzed) (Table I), despite the usual presence of hair (Table I).

\section{DISCUSSION}

According to the data presented in this study, M. glirina can be considered a generalist species, tending to be insectivore, as insects were the items most often found in the stomachs of subjects. CASELla \& CÁCERES (2006) found similar results for a species of the same genus, Monodelphis sorex (Hensel, 1872). According to Vieira \& Monteiro-Filho (2003), small cursorial animals tend to be insectivores. In fact, the most abundant group in the diet - Coleoptera, is not by chance the richest order of insects, and is invariably available anywhere (BORROR et al. 1992, Daly et al. 1998). Another aspect that determines the high abundance of beetles in the stomach contents of subjects is that the body of these insects is resistant to milling during digestion (PINHeIro et al. 2002).

Among the food items encountered, only "seeds" were not constant between the sexes and the classes of development.
However, according to PINHeIro et al. (2002), items of vegetable origin can be easily digested. The constancy of a diet can be related to different factors, such as the behavioral responses of the species in relation to the ecosystem where it inhabits. The selection and permanence of the animal in microhabitats with similar food resources can explain the constancy in dietary items (Fernandes et al. 2006).

Because of the different sizes of the forest fragments, differences in the diet of the subjects are possibly due to edge effects. According to Malcolm (1995), there are many secondary habitats in the smaller fragments. Due to edge effects, these places have fewer fruits and more insects. All fragments studied belong to a pasture matrix used for cattle ranching, which would explain the greater number of beetles, once they use feces for feeding and reproduction (MENDES \& LinHARES 2006). The greater consumption of beetles in the small fragments can be explained by the extension of the edge, which facilitates the entrance of beetles in areas of the forest. Once the size of the fragments increases, the availability of food becomes more diversified, and this marsupial can consume other food categories available and less coleopterans. Our data shows that this animal is opportunistic. Such opportunism is well known in other didelphids from the Neotropical region, which explore food resources according to their availability (Atramentowicz 1988, Medellín 1994, CÁceres et al. 1999). According to a study performed in the Mata Atlântica, the availability of food - such as fruits and arthropods - as well as the survival rates during the strong rainfall season has its peak in the beginning and in the end of the rainy period (Bergallo \& Magnusson 1999).

Probably, these effects were also responsible for higher rates of survival, because during May and September, 2009, the beginning and end of the rainy season, respectively, food is more largely available. The animals were captured in more numbers, and their body measurements were samaller than those obtained by Anderson (1997). These differences in size, which are not statistically significant, correspond to morphologic modifications through the years which may be directly linked to locomotion and, consequently, to the search for resources (VIEIRA 2003).

During the the current study, a daily high to intermediate feeding activity of $M$. glirina became evident by the fact that the majority of the stomachs analyzed had a high-intermediate amount of food. This activity index matched the high availability of Coleoptera between May and September (when the subjects were sampled). It is possible that the animals with empty stomachs were captured in the beginning of the night, having no opportunity for feeding outside the trap.

Besides Coleoptera, another item which is resistant to digestion is hair. It was present in the analysis. However, the absence of other contents from animal origin made us suppose that hair consumption was accidental, for instance through self-cleaning or collective cleaning, similar to what was reported by Fernandes et al. (2006). 
Table I. Diet categories of Monodelphis glirina in southern Amazon. (A) Abundance, (FO) Frequency of occurrence, (IFI) Importance food index.

\begin{tabular}{|c|c|c|c|c|c|c|c|c|c|}
\hline \multirow{2}{*}{ Category } & \multicolumn{3}{|c|}{ Males } & \multicolumn{3}{|c|}{ Females } & \multicolumn{3}{|c|}{ Juveniles } \\
\hline & A & $\mathrm{IFI}$ & FO & A & $\mathrm{IFI}$ & $\mathrm{FO}$ & A & $\mathrm{IFI}$ & $\mathrm{FO}$ \\
\hline Coleoptera & 57.80 & 0.3342 & 82.75 & 38.93 & 0.1515 & 100.00 & 61.61 & 0.3796 & 75.00 \\
\hline Orthoptera & 1.95 & 0.0003 & 20.68 & 2.85 & 0.0008 & 25.00 & 0.00 & 0.0000 & 0.00 \\
\hline Hymenoptera & 1.15 & 0.0001 & 17.24 & 6.04 & 0.0036 & 50.00 & 2.54 & 0.0006 & 25.00 \\
\hline Miscellaneous vegetal & 3.36 & 0.0011 & 17.24 & 2.17 & 0.0004 & 17.85 & 8.63 & 0.0074 & 12.50 \\
\hline Nematoda & 0.03 & - & 34.48 & 3.41 & - & 32.14 & 0.00 & - & 0.00 \\
\hline Diplopoda & 3.56 & 0.0012 & 3.44 & 13.03 & 0.0169 & 3.57 & 0.00 & 0.0000 & 0.00 \\
\hline Seed & 0.00 & 0.0000 & 0.00 & 0.27 & 0.0000 & 3.57 & 0.00 & 0.0000 & 0.00 \\
\hline Bait & 32.10 & - & 86.20 & 33.28 & - & 85.71 & 27.27 & - & 75.00 \\
\hline \multirow{2}{*}{ Category } & \multicolumn{3}{|c|}{ Subadults } & \multicolumn{3}{|c|}{ Adults } & \multicolumn{3}{|c|}{ Total } \\
\hline & $\mathrm{A}$ & $\mathrm{IFI}$ & $\mathrm{FO}$ & $\mathrm{A}$ & $\mathrm{IFI}$ & $\mathrm{FO}$ & $\mathrm{A}$ & $\mathrm{IFI}$ & FO \\
\hline Coleoptera & 54.37 & 0.2956 & 100.00 & 49.15 & 0.2415 & 92.30 & 50.00 & 0.2472 & 91.22 \\
\hline Orthoptera & 1.06 & 0.0001 & 10.00 & 2.72 & 0.0007 & 30.76 & 2.33 & 0.0005 & 22.80 \\
\hline Hymenoptera & 11.67 & 0.0136 & 50.00 & 2.25 & 0.0005 & 30.76 & 3.25 & 0.0010 & 33.33 \\
\hline Miscellaneous vegetal & 2.12 & 0.0004 & 10.00 & 2.64 & 0.0006 & 20.51 & 2.85 & 0.0008 & 17.54 \\
\hline Nematoda & 0.00 & - & 0.00 & 2.59 & - & 48.71 & 1.47 & - & 33.33 \\
\hline Diplopoda & 0.00 & 0.0000 & 0.00 & 9.37 & 0.0087 & 5.12 & 7.62 & 0.0058 & 19.29 \\
\hline Seed & 0.00 & 0.0000 & 10.00 & 0.00 & 0.0000 & 0.00 & 0.11 & 0.0000 & 1.75 \\
\hline Bait & 30.76 & - & 90.00 & 31.25 & - & 87.17 & 32.62 & - & 85.96 \\
\hline
\end{tabular}

Nematoda is not a food category. But these endoparasites might have influenced the food activity of the species, once M. glirina had a good portion of their stomachs filled with these nematodes, as already reported by Ribeiro et al. (2009) for Didelphis.

\section{ACKNOWLEDGEMENTS}

We thank the members from the Mammalogy Lab (CELBE) and the Universidade do Estado de Mato Grosso (UNEMAT). We also thank Paulo Roberto Mariotti for drawing the maps and to the anonymous reviewer had provided useful comments to the manuscript. We would like to thank the University of East Anglia (USA) and the Fundação de Amaparo à Pesquisa do Estado de Mato Grosso (FAPEMAT) for the financial support. Finally, tanks to IBAMA for issuing the collecting license (\#3998-1).

\section{LITERATURE CITED}

Anderson, S. 1997. Mammals of Bolivia, taxonomy and distribution. Bulletin of the American Museum of Natural History 231: 1-652.

Atramentowicz, M. 1988. La frugivorie opportuniste de trois marsupiaux didelphidés de Guyane. Revue d'Ecologie Terre et Vie 43: 47-57.

Bergallo, H.G \& W.E. Magnusson. 1999. Effects of climate and food availability on four rodent species in southeastern
Brazil. Journal of Mammalogy 80 (2): 472-486.

Borrror, T.J; C.A. Triplehorn \& N.F. JohnSon. 1992. An introduction to the study of insects. Orlando, Harcourt, $875 \mathrm{p}$.

Cáceres, N.C.; V.A.O. Dittrich \& E.L.A. Monteiro-Filho. 1999. Fruit consumption, distance of seed dispersal and germination of Solanaceous plants ingested by the common opossum (Didelphis aurita) in southern Brazil. Revue d'Ecologie Terre et Vie 54: 225-234.

CAsella, J. \& N. CÁCeres. 2006. Diet of four small mammal species from Atlantic forest patches in South Brazil. Neotropical Biology and Conservation 1 (1): 5-11.

Cordero, A. \& A. Nicolas. 1987. Feeding habits of the opossum (Didelphis marsupialis) in Northern Venezuela. Fieldiana, Zoology (39): 125-131.

Costello, M.J. 1990. Predator feeding strategy and prey importance: a new graphical analysis. Journal of Fish Biology 36: 261-263. doi: 10.1111/j.1095-8649.1990.tb05601.x

Daly, V.H.; J.T. Doyen \& A.H. Purcell, III. 1998. Introduction to insect biology and diversity. New York, Oxford University Press, $2^{\text {nd }}$ ed., 680p.

EMmons, L.H. \& F. FeER. 1997. Neotropical rainforest mammals: a field guide. Chicago, University of Chicago Press, $2^{\text {nd }}$ ed., $307 p$.

Fernandes, M.E.B.; F.A.G. Andrade \& J.S.S. Júnior. 2006. Dieta de Micoureus demerarae (Thomas) (Mammalia, Didelphidae) associada às florestas contíguas de mangue e terra firme em Bragança, Pará, Brasil. Revista Brasileira de Zoologia 23 (4): 1087-1092. 
Fernandez, F.A.S. \& A.S. Pires. 2006. Perspectivas para a sobrevivência dos marsupiais brasileiros em fragmentos florestais: o que sabemos, e o que precisamos ainda aprender?, p. 191-201. In: N.C. CÁCeres \& E. MONTEIRo-FIlHo. (Orgs). Os Marsupiais do Brasil: Biologia, Ecologia e Evolução. Campo Grande, Editora da Universidade Federal de Mato Grosso do Sul, 364p.

Gardner, A.L. 2005. Order Didelphimorphia, p. 3-18. In: D.E. Wilson \& D.M. ReEder (Eds). Mammal species of the world: a taxonomic and geographic reference. Baltimore, The Johns Hopkins University Press, $3^{\text {rd }}$ ed., 2142p.

Hensel, R. 1872. Beiträge zue Kenntniss der Säugethiere SüdBrasiliens - Abhandl. König. Akad. Wiss. Berlin. 1-130.

Hynes, H.B.N. 1950. The food of fresh-water sticklebacks (Gasterosteus aculeatus and Pygosteus pungitius) with a review of methods used in studies of the food of fishes. Journal of Animal Ecology 19: 36-58.

Hyslop, E.J. 1980. Stomach contens analysis - a review of methods and their applications. Journal of Fish Biology 17: 411-429.

KaWAKami, E. \& G. Vazzoler. 1980. Método gráfico e estimativa de índice alimentar aplicado no estudo da alimentação de peixes. Boletim do Instituto Oceanográfico 29: 205-207.

Laurance, W.F. \& R.O. Bierregandd. 1997. Tropical Forest Remnants. Ecology, Management, and Conservation of Fragmented Communities. Chicago, University of Chicago Press, 1-110.

Lovejoy, T.E; R.O. Bierregaard Júnior; A.B. Rylands; C.E. Quintela; L.H. Harper; K.S. Brown Júnior; A.H. Powell; G.V.N. Powell; H.O.R. Schubart \& M.B Hays. 1986. Edge and other effects of isolation on Amazon Forest fragments, p. 257-285. In: M.E. Soulé. (Ed.). Conservation biology: the science of scarcity and diversity. Sunderland, Sinauer Associates, 584p.

Macedo, J.; D. Loretto; M.V. Vieira \& R. Cerqueira. 2006. Classes de desenvolvimento em marsupiais: Um método para animais vivos. Mastozoologia Neotropical 13 (1): 133-136.

Malcolm, J.R. 1995. Forest structure and the abundance and diversity of neotropical small mammals, p. p. 179-197. In: M.D. Lowman N.M. NADKarni (Eds). Forest Canopies. San Diego, Academic Press, 624 p.

Medellín, R.A. 1994. Seed dispersal of Cecropia obtusifolia by two species of opossums in the Selva Lacandona, Chiapas,
Mexico. Biotropica 26 (4): 400-407.

Mendes, J. \& A.X. Linhares. 2006. Coleoptera associated with undisturbed cow pats in pastures in Southeastern Brazil. Neotropical Entomology 35 (6): 715-723.

Michalski, F. \& C.A. Peres. 2005. Anthropogenic determinants of primate and carnivore local extinctions in a fragmented forest landscape of southern Amazonia. Biological Conservation 124: 383-396.

MurCia, C. 1995. Edge effects in fragmented populations: implications for conservation. Trends in Ecology and Evolution (1): 58-62.

NowAK, R.M. 1991. Walker's Mammals of the World. Baltimore, The Johns Hopkins University Press, vol. 1, $5^{\text {th }}$ ed., 1629p.

Pinheiro, O.S.; F.M.V. Carvalho; F.A.Z. Fernandez \& J.L. Nessimian. 2002. Diet of Marsupial Micoureus demerarae in Small Fragments of Atlantic Forest in Southeastern Brazil. Studies on Neotropical Fauna and Environment 37: 213-218.

R Development Core Team. 2011. R: A language and environment for statistical computing. Vienna, R Foundation for Statistical Computing, ISBN 3-900051-07-0, available online at: http://www.R-project.org

Reis, N.R.; A.L. Peracchi; W.A. Pedro \& I.P. Lima. 2006. Mamíferos do Brasil. Londrina, Universidade Estadual de Londrina, 437p.

Ribeiro, M.C.; J.P. Metzger; A.C. Martensen; F.J. Ponzoni \& M.M. Hirota. 2009. The Brazilian Atlantic Forest: How much is left, and how is the remaining forest distributed? Implications for conservation. Biological Conservation 142: 1141-1153.

Santori, R.T. \& D. Astúa De Moraes. 2006. Alimentação, nutrição e adaptações alimentares de marsupiais brasileiros, p. 241-254. In: E.L.A. Monteiro-Filho \& N.T. Cáceres (Eds). Os marsupiais do Brasil: biologia, ecologia e evolução. Campo Grande, Editora UFMS, p364.

Tribe, C.J. 1990. Dental age classes in Marmosa incana and others Didelphoids. Journal of Mammalogy 71 (4): 566-569.

Uieda, V. 1994. Métodos Para Cuantificar contenidos estomacales en peces. Universidad de Los Llanos, p37.

Vieira, E.M. \& E.L.A. MonTeiro-Filho. 2003. Vertical stratification of small mammals in the Atlantic rain Forest of southeastern Brazil. Journal of Tropical Ecology 19: 501-507.

Submitted: 06.XII.2011; Accepted: 18.XII.2012.

Editorial responsibility: Fernando de C. Passos 